\title{
Correlation between Workers' Characteristics and Health Complaints Due to Exposure to Organic Solvents in the Sidoarjo Offset Printing
}

\author{
Hubungan antara Karakteristik Pekerja dengan Keluhan Kesehatan Akibat \\ Pajanan Pelarut Organik di Percetakan Sidoarjo
}

\author{
Bening Kusuma Ramadhini, Lilis Sulistyorini \\ Department of Environmental Health, Faculty of Public Health Universitas Airlangga \\ Campus C Mulyorejo, Surabaya, East Java 60155 Indonesia
}

\begin{abstract}
Introduction: Organic solvents are chemicals that are often used by the printing industry and contain Benzene, Toluene, and Xylene which are toxic to humans. Chemicals that contain organic solvents are ink, glue, and others. Workers who are regularly exposed to organic solvents can have health complaints. The purpose of this study was to determine the correlation between workers' characteristics and health complaints due to exposure to organic solvents in the Sidoarjo offset printing. Methods: This research was an observational study with cross sectional design. Population in this research was 30 workers. The sampling technique used simple random sampling and from the calculation results were obtained 24 respondents. This study had an independent variable, which was workers' characteristics consisting of age, smoking habits, and work tenure. The dependent variable was health complaints of printing workers. Data collection used questionnaires and interviews. The research data were analyzed using fisher's exact test to show the correlation between workers' characteristics and health complaints. Results: The result of the analysis test found that there was no correlation between age $(p=0.386)$ and smoking habits $(p=0.376)$ with health complaints of workers. Moreover, the analysis test showed that work tenure variable had a correlation with health complaints of workers $(p=0.041)$. Conclusion: A factor related to health complaints of workers was work tenure.
\end{abstract}

Keywords: health complaints, organic solvents, worker characteristics

\section{ABSTRAK}

Pendahuluan: Pelarut organik merupakan bahan kimia yang sering digunakan industry percetakan dan mengandung Benzena, Toluena, dan Xilena (BTX) yang bersifat toksik bagi manusia. Bahan kimia yang mengandung pelarut organik yaitu tinta, lem, dan lain-lain. Pekerja yang terpajan pelarut organik secara rutin dapat menimbulkan keluhan kesehatan. Tujuan penelitian ini yaitu untuk mengetahui hubungan karakteristik pekerja dengan keluhan kesehatan akibat pajanan pelarut organic di percetakan offset Sidoarjo. Metode: Penelitian ini merupakan observasional dengan rancang bangun cross sectional. Populasi dalam penelitian ini sebanyak 30 pekerja. Teknik pengambilan sampel menggunakan simple random sampling dan dari hasil perhitungan didapatkan sebanyak 24 responden. Variabel independen penelitian ini yaitu karakteristik pekerja yang terdiri dari usia, kebiasaan merokok, dan masa kerja. Variable dependen yaitu keluhan kesehatan pekerja percetakan. Pengambilan data mengguanakan kuesioner dan wawancara. Data hasil penelitian dianalisis menggunakan uji fisher's exact untuk menunjukkan hubungan karakteristik pekerja dengan keluhan kesehatan. Hasil: Hasil uji analisis didapatkan tidak terdapat hubungan antara usia $(p=0,386)$ dan kebiasaan merokok $(p=0,376)$ dengan keluhan kesehatan pekerja. Uji analisis pada variable masa kerja terdapat hubunggan dengan keluhan kesehatan pekerja (p=0,041). Simpulan: Faktor yang berhubungan dengan keluhan kesehatan pekerja yaitu masa kerja yang dimiliki pekerja percetakan.

Kata kunci: karakteristik pekerja, keluhan kesehatan, pelarut organik

Corresponding Author:

Bening Kusuma Ramadhini

Email: beningramadhini@gmail.com

Telephone: +6281333647971

\section{INTRODUCTION}

The printing industry is one of the industries that contributes to improve the economy. The printing industry in Indonesia consists of various types of printing, which one is offset printing. Offset printing is a printing company that produces 
brochures, magazines, calendars, newspapers, books, and others. The industry involves a lot of chemicals, including glue, ink, plate cleaners, and other chemicals. Moreover, the printing press always involves various chemicals that are not controlled properly. In fact, the growing times in this modern era have made the offset printing industry continue to produce. This is because the products are produced based on communication and the latest information.

The more offset printing develops, the more a company involves many people to work in it. This can have a positive impact on society because there are more job opportunities available. However, it not always only brings profit but also there negative impacts from creating jobs in the printing industry. The negative effect caused is that more workers are exposed to chemicals during the work process because the printing industry involves a lot of chemicals in it.

The chemicals used in the printing industry contain organic solvents or what is commonly called Volatile Organic Compound. The organic solvent contains toxic subtances, namely Benzene, Toluene, and Xylene (BTX). This material is a Polycyclic Aromatic Hydrocarbon (PAH) compound which can be formed due to incomplete combustion (Wispriyono and Handoyo, 2016). These organic solvents often have toxic effects on the human body. The effect of exposure to organic solvents is very dangerous for the human body because it has nonpolar properties and can accumulate in fatty tissue, so it can cause chronic effects on health. Workers who are regularly exposed to organic solvents will develop neurotoxic complaints. High BTX levels can also interfere with the bone marrow in blood formation, change DNA, and affect the immune system. Regular exposure to light levels can cause complaints of dizziness, nausea, headaches, and others. Other symptoms that most often arise are characterized by leukocytopenia, thrombocytopenia, and anemia (Singh, Neetu and Jain, 2012). Other health complaints arising from exposure to organic solvents are complaints of the central nervous system such as fatigue, dizziness, headaches, and death (Kumar and Subhashini, 2015).

Health complaints arising from benzene exposure include kidney problems, digestive complaints, neurogical complaints, and haematological disorders. The most dominant complaints often felt by workers exposed to benzene are neurogical complaints and kidney disorders
(Resdwivani, 2018). Meanwhile, health effects due to toluene exposure are peripheral nerve neuropathy and inhalation complaints in 3 printing workers who worked for 79.8 months (Pratamasari, Setyopranoto and Soebijanto, 2016). The effects that occur on workers exposed to xylene include depression in the central nervous system, dizziness, headaches, nausea, and others. These complaints will arise if the xylene is exposed to $100 \mathrm{ppm}$. The haematological effect due to xylene exposure is anemia (Kandyala, Raghavendra and Rajasekharan, 2010). Generally, chronic and acute effects due to xylene exposure are of the same type as the effects which occur due to exposure to other organic solvents such as nervous system complaints (Clough, 2014).

Research conducted in the printing industry in Rungkut has proven that the presence of toluene in the work environment exceeded the threshold value of $72.51 \mathrm{ppm}$ in the printing room and workers experienced eye irritation complaints (Irmasari, 2018). Another study conducted in the Medan printing industry found that benzene measurements were $1.6 \mathrm{ppm}$ and workers experienced health complaints such as shortness of breath, nausea, headaches, etc (Siregar, Ashar and Nurmaini, 2019). Based on the cases found in the previous studies, this study aims to determine the correlation between workers' characteristics and health complaints due to exposure to organic solvents in the Sidoarjo offset printing.

\section{METHODS}

This study was an observational study with a cross sectional design. This is because the measurements are made at the same time. The location of this research was located in one of the offset printings in Sidoarjo, East Java.

The population of this research was all workers who worked in the printing industry as many as 30 printing workers. The sample calculation technique used simple random sampling, and this study obtained a sample of 24 respondents. Sampling was taken randomly, so that every worker had the same opportunity as a respondent. The independent variables of this study $\mathrm{w}$ were the characteristics of workers consisting of age, smoking habits, and work tenure. Meanwhile, the dependent variable of this study was health complaints. Data on this research were analyzed using Fisher's exact test.

This research was conducted in March -June 2020. The data in this study were collected 
through interviews based on questionnaires and observations. Printing workers were interviewed regarding the characteristics of workers consisting of age, smoking habits, work tenure, and health complaints. Meanwhile, observations were made to determine the exposure to organic solvents in the printing work environment. This research has passed the ethical clearance of the Faculty of Dentistry, Airlangga University with certificate number $270 /$ HRECCFODM/VI/2020.

\section{RESULTS}

\section{Organic Solvents in the Sidoarjo Offset Printing}

The chemicals contained in the Sidoarjo offset printing are inks, ink cleaners, ink thinners, plate cleaners, oil, glue, and others. These materials are a source of benzene exposure that is in the printer. Printing workers have the potential to be exposed to these chemicals due to direct contact, especially at the printing press. However, it does not preclude if workers in other sections are also in contact with these materials because they sometimes receive chemicals that have just come from the factory.

The printing press consumes one can of ink, and the quantity depends on how much the order is. The cleaning ink used consumes 1 drum/month. Ink cleaners are usually used to clean ink-stained tools and hands. For plate cleaner, the industry spends 1 can for 2-3 weeks. The oil that is used to smooth the running of production machines is rarely used up. Specifically, there are 2 types of glue used in the form of one, consisting of yellow glue and clear glue. For the yellow glue, 1 sack can be used for 2-3 months, while 2 sacks of clear glue can be used for 1 month. Furthermore, the workers should put chemicals in a special room that has been provided.

During the production process, workers are in direct contact with these materials without wearing gloves, especially printing machine workers. The results of observations show that workers cleaned the printed plates by hand without any PPE used.

Table 1. Health Complaint Distribution of Offset Printing Workers, Sidoarjo in 2020

\begin{tabular}{ccc}
\hline H $\underset{2}{\text { e }}$ l t & \multicolumn{2}{c}{ Frequency } \\
Complaints & $\mathbf{n}$ & $\mathbf{\%}$ \\
\hline Mild-Moderate & 13 & 54.2 \\
Severe & 11 & 45.8 \\
\hline Total & 24 & 100.0 \\
\hline
\end{tabular}

The habit of printing workers not to wear PPE gloves can cause chemicals containing organic solvents to enter the body through the skin.

\section{Health Complaints}

Health complaints in Table 1 are divided into 2 categories based on the number of complaints that were felt by workers, namely mild-moderate and severe complaints. A total of 13 workers $(54.2 \%)$ had mild-moderate complaints and as many as 11 respondents $(45.8 \%)$ had health complaints in the severe category workers.

Health complaints experienced by 24 respondents due to benzene exposure were dizziness (17 respondents), headache (15 respondents), sleep disturbance (6 respondents), decreased concentration (1 respondents), joint pain (11 respondents), leg pain (11 respondents), hand pain (6 respondents), shortness of breath (11 respondents), palpitations ( 5 respondents), chest pain (1 respondent), weakness / lethargy (10 respondents), trembling hands (3 respondents), a lack of energy (8 respondents) ), fatigue (14 respondents), staggering ( 2 respondents), drowsiness (15 respondents), nausea (4 respondents), vomiting 2 respondents, abdominal pain (4 respondents), decreased appetite ( 5 respondents), frequent urination ( 5 respondents), and low back pain (7 respondents). The health complaints felt by workers, most of them were neurological complaints, namely complaints of dizziness, headache, fatigue, and easily drowsiness.

\section{Age}

Table 2 shows the age of printing workers. 17 workers $(70.8 \%)$ were in the category of $\leq 45$ years old and 7 workers $(29.2 \%)$ were in the the category of $>45$ years old.

\section{Smoking Habits}

Table 3 shows that 19 respondents (79.2\%) had no-smoking habits and 5 respondents $(20.8 \%)$ had smoking habits.

Table 2. Age Distribution of Sidoarjo of Offset Printing Workers, Sidoarjo in 2020

\begin{tabular}{ccc}
\hline \multirow{2}{*}{ Age (year) } & \multicolumn{2}{c}{ Frequency } \\
\cline { 2 - 3 } & $\mathbf{n}$ & \% \\
\hline$\leq 45$ & 17 & 70.8 \\
$>45$ & 7 & 29.2 \\
\hline Total & 24 & 100.0 \\
\hline
\end{tabular}


Table 3. Distribution of Smoking Habits of Offset Printing Workers, Sidoarjo in 2020

\begin{tabular}{ccc}
\hline \multirow{2}{*}{ Smoking Habits } & \multicolumn{2}{c}{ Frequency } \\
\cline { 2 - 3 } & $\mathbf{n}$ & $\mathbf{\%}$ \\
\hline No-smoking & 19 & 79.2 \\
Smoking & 5 & 20.8 \\
\hline Total & 24 & 100.0 \\
\hline
\end{tabular}

Table 4. Distribution of Work Tenure of Offset Printing Workers, Sidoarjo in 2020

\begin{tabular}{ccc}
\hline \multirow{2}{*}{\begin{tabular}{c} 
Work $\begin{array}{c}\text { Tenure } \\
\text { (years) }\end{array}$ \\
\cline { 2 - 3 }
\end{tabular}} & $\mathbf{n}$ & Frequency \\
\hline$<10$ & 5 & 20.8 \\
$\geq 10$ & 19 & 79.2 \\
\hline Total & 24 & 100.0 \\
\hline
\end{tabular}

Table 5. Correlation between Age and Health Complaints of Offset Printing Workers, Sidoarjo in 2020

\begin{tabular}{|c|c|c|c|c|c|c|}
\hline \multirow{3}{*}{ Age (year) } & \multicolumn{4}{|c|}{ Health Complaints } & \multirow{2}{*}{\multicolumn{2}{|c|}{ Total }} \\
\hline & \multicolumn{2}{|c|}{$\begin{array}{l}\text { M i l d - } \\
\text { Moderate }\end{array}$} & \multicolumn{2}{|c|}{ Severe } & & \\
\hline & $\mathrm{n}$ & $\%$ & $\mathrm{n}$ & $\%$ & $\mathrm{~N}$ & $\%$ \\
\hline$\leq 45$ & 8 & 47.1 & 9 & 52.9 & 17 & 100.0 \\
\hline$>45$ & 5 & 71.4 & 2 & 28.6 & 7 & 100.0 \\
\hline $\begin{array}{l}\text { Exact Sig. } \\
\text { (2-sided) }\end{array}$ & \multicolumn{4}{|c|}{0.386} & & \\
\hline
\end{tabular}

\section{Work Tenure}

Table 4 shows work tenure of offset printing workers in Sidoarjo. It can be seen that 19 printing workers $(79.2 \%)$ had work tenure $\geq 10$ years.

\section{Correlation between Age and Health Complaints}

The results of the statistical test in Table 5 show that there was no correlation between age and health complaints. The significance value obtained was 0.386 .

\section{Correlation between Smoking Habits and Health Complaints}

The statistical test in Table 6 shows a significance value of 0.376 . This means that there was no correlation between smoking habits and health complaints.
Table 6. Correlation between Smoking Habits and Health Complaints of Offset Printing Workers, Sidoarjo in 2020

\begin{tabular}{|c|c|c|c|c|c|c|}
\hline \multirow{3}{*}{$\begin{array}{c}\text { S m o k i n g } \\
\text { Habits }\end{array}$} & \multicolumn{4}{|c|}{ Health Complaints } & \multirow{2}{*}{\multicolumn{2}{|c|}{ Total }} \\
\hline & \multicolumn{2}{|c|}{$\begin{array}{l}\text { M i I d - } \\
\text { Moderate }\end{array}$} & \multicolumn{2}{|c|}{ Severe } & & \\
\hline & $\mathrm{n}$ & $\%$ & $\mathrm{n}$ & $\%$ & $\mathrm{~N}$ & $\%$ \\
\hline $\begin{array}{c}\text { No- } \\
\text { smoking }\end{array}$ & 10 & 52.6 & 9 & 47.4 & 19 & 100.0 \\
\hline Smoking & 3 & 60.0 & 2 & 40.0 & 5 & 100.0 \\
\hline $\begin{array}{l}\text { Exact Sig. } \\
\text { (2-sided) }\end{array}$ & \multicolumn{4}{|c|}{0.376} & & \\
\hline
\end{tabular}

Table 7. Correlation between Work Tenure and Health Complaints of Offset Printing Workers, Sidoarjo in 2020

\begin{tabular}{|c|c|c|c|c|c|c|}
\hline \multirow{3}{*}{$\begin{array}{c}\text { W o r k } \\
\text { T e n u r e } \\
\quad \text { (year) }\end{array}$} & \multicolumn{4}{|c|}{ Health Complaints } & \multirow{2}{*}{\multicolumn{2}{|c|}{ Total }} \\
\hline & \multicolumn{2}{|c|}{$\begin{array}{l}\text { M i l d - } \\
\text { Moderate }\end{array}$} & \multicolumn{2}{|c|}{ Severe } & & \\
\hline & $\mathrm{n}$ & $\%$ & $\mathrm{n}$ & $\%$ & $\mathrm{~N}$ & $\%$ \\
\hline$<10$ & 5 & 100.0 & 0 & 0.0 & 5 & 100.0 \\
\hline$\geq 10$ & 8 & 42.1 & 11 & 57.9 & 19 & 100.0 \\
\hline $\begin{array}{l}\text { Exact Sig. } \\
\text { (2-sided) }\end{array}$ & \multicolumn{4}{|c|}{0.041} & & \\
\hline
\end{tabular}

Correlation between Work Tenure and Health Complaints

The correlation test in Table 7 shows a significance value of 0.041 . This means that there was a correlation between tenure and health complaints.

\section{DISCUSSION}

\section{Organic Solvents in Sidoarjo Offset Printing}

Printing uses materials that contain benzene such as plate cleaner, preserver gum, printing ink, engine lubricants, and gasoline in the printer so that the benzene content in a room increases (Febriantika, Sulistyani and Budiyono, 2017). Yellow glue contains $0.1 \%$ benzene and $55 \%$ toluene, while clear glue contains 55\% toluene in it (Laelasari, Kristanti and Rahmat, 2018).

Based on the results of interviews, printing workers in the printing press had contact frequency with chemicals around 15-32 times / day depending on how many goods were produced. However, in 
some other occasion, the contact frequency was less than about 5 times / day. This is because workers only receive chemicals that have just come from the factory and store these materials in a special place.

Printing workers also stated that they poured ink onto the machine rollers using a plastic tool. Workers cleaned the images on the printing plate using only their hands after which the plate was wiped using a cloth. In addition, if you clean the plate from dirt using a sponge. However, when working, printing workers did not wear gloves so that they were potentially exposed to benzene, coming from the chemicals used.

Printing workers admitted that if their hands were exposed to ink or chemicals, they did not wash their hands immediately with soap and running water. However, they chose to wait for rest hours and the end of work. The ink cleaner used wasa substitute for a mixture of gasoline and kerosene. Workers admitted that the chemical used today to clean ink is a mixture of gasoline and kerosene. Ink cleaners were provided in each printing machine, so workers could clean the ink at any time with the liquid. Based on observations, after the workers' hands were cleaned using the liquid, the workers dried their hands using the cloth that had been provided. The printing worker stated that the cloth used would be changed every month. The large number of chemicals that contain organic solvents in the workplace has the potential for workers to be exposed to organic solvents, especially through the skin. This is because workers do not use gloves when working.

Organic solvents have volatile properties. The accumulation of organic solvent vapor in the Sidoarjo offset press came from a vent that did not meet the standards. The results of observations found that there was no ventilation in the study site. The company had an exhaust fan that functioned as an air exchange in the room. However, the Sidoarjo offset printing exhaust fan did not work because the local residents were disturbed by the noise from the device. Yet, the Sidoarjo offset printing company set regulations regarding the use of PPE in the form of surgery masks and safety shoes. The printing company also provided surgery masks and safety shoes.

Organic solvent exposure in the printing press can be affected by whether or not the air circulation in the room is good and the availability of ventilation. Poor air circulation can increase the risk of exposure to organic solvents in workers (Laelasari, Kristanti and Rahmat, 2018). Ventilation in the workplace can reduce benzene exposure by up to $43 \%$ and toluene exposure by up to $47 \%$. Windows in the room can contribute to reduce indoor benzene by $78 \%$ and toluene by $84 \%$ (Vermeulen et al., 2004). Therefore, health complaints felt by workers can be reduced by conducting a risk assessment related to the toxicology of the chemicals used. Another way to reduce workers' health complaints is to arrange work space and create a partition in the workplace to reduce exposure (Azari et al., 2012).

The availability of PPE in offset printing is still not up to standard. Surgery masks cannot withstand exposure to gases such as organic solvents as they evaporate in the air. In fact, surgery masks are different from respirator masks because surgery masks still do not cover the nose and mouth completely (Faisal and Susanto, 2019). Overall, the availability of PPE in the form of safety shoes at the Sidoarjo offset printing shop is good. This is to avoid skin contact if the chemicals used are spilled so that they do not come into contact with the skin directly.

The habit of workers of not wearing PPE gloves can increase the exposure to organic solvents into the body. This habit is influenced by the fact that the company did not implement regulations regarding the use of gloves and workers' lack of knowledge about the dangers of chemicals when exposed to skin. Exposure to chemicals in the work environment can occur intentionally, indirectly, once in contact, and even repeatedly. Previous research conducted on workers in shoe workshops found skin irritation in workers. This is because workers did not wear PPE in the form of gloves while working (Rauf et al., 2015). The habit of workers of not using gloves while working can increase the risk of exposure to chemicals into the body, while workers who use gloves at work have a smaller risk of exposure to chemicals (Khan, Sultan and Rahman, 2013).

\section{Age}

Most of the offset printing workers in Sidoarjo were around $\leq 45$ years old. However, there were some workers with the age category of $>45$ years as many as 7 workers. Specifically, the youngest age of printing workers in this study was 30 years old and the oldest was 55 years old. Based on the results of the interviews, all workers started working in the printing industry at around the age of 20 years and over. Printing workers also admitted that they had previously had experience in printing. 
A person's immune system will decrease with age. If the immune system is weakened, it will be more vulnarable and at higher risk for experiencing health complaints. Age around $\leq 45$ years is still not considered susceptible to exposure to toxic substances. This is because the body power produced is still good (Erini Meilina Bestari, Sudarmaji, 2019). Research conducted in Thailand on the printing industry showed that workers who were $>40$ years old were at risk of being exposed to chemicals in the work environment so that they could cause neurological and psychosomatic complaints. These complaints included headaches, sweating without any cause, weakness, lethargy, loss of libido, decreased appetite, and others (Thetkathuek et al., 2015). Moreover, research conducted in the shoemaking industry found that the physical quality of the human body of workers aged $>45$ years old had had decreased. Age workers over 45 are more exposed to chemicals, which can cause many health effects (Fahmi, 2017). The effect of toluene exposure will be more pronounced if a person's age is getting older (Pratamasari, Setyopranoto and Soebijanto, 2016).

\section{Smoking Habits}

Based on the results on this study, it can be seen that printing workers mostly had a no-smoking habit. Only 5 workers who had smoking habits out of 24 workers. Cigarette smoke contains organic solvents, one of which is benzene (ATSDR, 2007). In addition to benzene, cigarette smoke also contains other organic solvents such as toluene and xylene. Research that has been conducted in America stated that smoke from cigarettes was a source of benzene. The results of this study noted that the average benzene consumed by people who consumed cigarettes was 10 times more than the average benzene of those who did not smoke or just inhaled cigarette smoke (Egeghy, Tornero-Velez and Rappaport, 2000). The metabolism of benzene in the body in smokers is much more than in nonsmokers. This is because a smoking habit becomes a source of benzene exposure to the human body (Wulandari et al., 2018). Smoking habits can also increase the greater risk of toluene exposure (ATSDR, 2015). Smoke from cigarettes is a source of exposure to organic solvents (Chin et al., 2014).

\section{Work Tenure}

The work tenure measured in this study was in a matter of years from the time the printing workers started working at the place until the time this research took place. Printing workers with a service life of $\geq 10$ years were 19 workers.

A working period of $>3$ years has the potential for benzene poisoning (Yunita, 2016). Meanwhile, working period $>30$ years can cause non-carcinogenic effects on workers exposed to chemicals (EPA, 2002). Moreover, the duration of contact with chemicals will affect the health effects it causes. The longer the worker is in contact with benzene, the greater the benzene level enters the body and causes health problems (Bada, 2017). Furthermore, research conducted at the Surabaya rungkut printing company found that workers with a working period of 19 years were at high risk of exposure to toluene in the workplace (Irmasari, 2018).

\section{Health Complaints}

Health complaints in this study were measured using a questionnaire and did not involve a doctor's diagnosis. Health complaints that were often experienced by printing workers were dizziness, headaches, tiredness and drowsiness. Health complaints felt by workers were nervous system disorders. Nervous system complaints will arise after benzene exposure enters through the inhalation route (ATSDR, 2007). Another health complaint was found in taxi drivers who were exposed to benzene during work which came from ambient air. Health complaints that were felt by taxi drivers were neurological complaints, digestion, and fatigue (Kasemy et al., 2019). Research conducted on glue users also showed that health complaints that often arose in workers were hallucinations, dizziness, frequent confusion, vertigo, and others (Jayanth et al., 2017).

The results of research conducted at car painting workshops showed that workers in the painting department tended to have complaints of the central nervous system due to exposure to toluene compared to those in the administration and finishing sections (Agustina and Mukono, 2017). For workshop workers in Makassar, the results showed that the majority of workshop workers experienced complaints of dizziness, fatigue and weakness at work so that it could affect productivity and decreased work ability (Syafar and Wahid, 2015). Complaints experienced by these workers included forgetfulness, erratic mood changes, headaches, weakness in the hands and feet, and trembling hands. Meanwhile, research in the Semarang 
printing company showed that workers experienced health problems, namely haematological disorders. The study stated that abnormal blood cells were an early indication for low levels of benzene exposure (Nikmah, Darundiati and Budiyono, 2016).

Workers with serious health complaints are mostly found in the printing press. Some people even experience serious health complaints because they have a previous history of disease such as respiratory disease. Health complaints in the severe category arise because workers in the printing press are often in direct contact with large quantities of chemicals than workers in other parts.

This study shows that the health complaints felt by workers were the result of exposure to organic solvents in the work environment. Printing workers would feel more dangerous health effects if there was no intervention from the company.

\section{Correlation between Age and Health Complaints}

The results of statistical tests showed that there was no correlation between age and health complaints. This is because 17 printing workers were aged $\leq 45$ years old, so the statistical test of this study was not related. Previous research conducted at the Semarang printing company foundthat age was not the only factor that affected health complaints but there were other factors, such as history of disease and length of work of workers (Febriantika, Sulistyani and Budiyono, 2017).

This research is in line with previous research conducted in the printing industry which stated that there was no relationship between age and complaints of the central nervous system (Marganda, Ashar and Nurmaini, 2018). Another research that is in line with this research is the study on workshop workers in New Zealand. The results of this study found that there was no relationship between age and neurotoxic complaints (Keer et al., 2017).

\section{The Correlation between Smoking Habits and Health Complaints}

Testing the correlation between smoking habits and health complaints of workers in this study showed no correlation because in this study most of printing workers had a no-smoking habit. This research is not in line with research conducted in Medan printing, suggesting that smoking habits could affect complaints of the central nervous system (Marganda, Ashar and Nurmaini, 2018). Workers who have a smoking habit are a group at risk for experiencing health complaints (Laelasari, Kristanti and Rahmat, 2018). This is because smoking can cause changes in the function and structure of the airways and lungs so that it can experience several health problems (Frizka and Martiana, 2017).

The offset printing press in Sidoarjo has stipulated a smoking ban while working. Based on the results of the interview, the Head of production stated that the prohibition was made to minimize fires because the work environment in the printing shop involved many explosive chemicals. It can be seen in Table 2 that most of the offset printing workers in Sidoarjo had a habit of not smoking. Meanwhile, workers who smoked only spent $<10$ cigarettes / day. Workers who had a smoking habit, usually consumed cigarattes outside of working hours when they finished working. The no-smoking habit of workers in offset printing can reduce exposure to organic solvents in the workplace so that the exposure to organic solvents originating from cigarette smoke is very small.

\section{Correlation between Work Tenure and Health Complaints}

The results of this study indicate that the variable length of service with health complaints was correlated. This is because all workers had a long working period so they were exposed to organic solvents for quite a long time, causinghealth complaints. The shorthest working period of Sidoarjo offset printing workers was 5 years and the maximum was 21 years.

The result of this research is the same as research conducted in the small industry at Mojokerto stating that there was relationship betweeen work tenure and health complaints. The study stated that the longer a person's work tenure, the longer the person was exposed to sources of danger and the more vulnerable the workers were to health problems (Frizka and Martiana, 2017). In fact, work tenure can affect the length of exposure received by workers. The longer the work tenure, the longer the exposure to chemicals received (Setiowati, 2018). Besides, research conducted at a traditional oil mining found that workers had an average work tenure of more than 10 years. This can cause the accumulation of benzene levels to increase with prolonged benzene exposure (Saadatuddaroini and Keman, 2019). The offset printing workers have already been classified as being exposed to a large amount of benzene because the printing 
worker's working period tends to be long. In this study,workers complained about health complaints they felt while working. Furthermore, Sseveral printing workers admitted that they had previously worked at other printing establishments. Therefore, it can affect the exposure that enters the body in large numbers because before working in the printing shop, they have been exposed to benzene in the work environment for a long time.

\section{CONCLUSION}

The results of this study concluded that there was no correlation between age and smoking habits with health complaints of printing workers. The tenure had a correlation with print workers' health complaints. Therefore, it is highly suggested for companies to carry out regular complete health checks to determine the health condition of printing workers at least once a year.

\section{ACKNOWLEDGEMENTS}

Researchers are grateful to the Head of the Sidoarjo offset printing company and all employees for allowing researchers to conduct research and for their participation in this research.

\section{REFERENCES}

Agustina, U. and Mukono, J. (2017) 'Keluhan Sistem Saraf Pusat pada Pekerja yang Terpapar Toluen di Udara di Bengkel Pengecatan Mobil di Surabaya', Jurnal Kesehatan Lingkungan, 9(1), pp. 31-39.

ATSDR (2007) Toxicological Profile For Benzene, U.S. Department Of Health And Human Services, Public Health Service. Atlanta, Georgia.

ATSDR (2015) 'Draft Toxicological Profile for Toluene', U.S. Department of Health and Human Services.

Azari, M. R. et al. (2012) 'Evaluation OfOccupational Exposure Of Shoe Makers To Benzene And Toluene Compounds In Shoe Manufacturing Workshops In East Tehran', Tanaffos, 11(4), pp. 43-49.

Bada, S. S. E. (2017) Analisis Hubungan Paparan Benzena Dan Kadar Trans, Trans Muconic Acid (TT-MA) Urin Dengan Profil Darah Pengrajin Sepatu Di Kelurahan Tambak Oso Wilangun Surabaya. Undergraduate Thesis. Surabaya: Faculty of Public Health, Universitas Airlangga.
Chin, J. Y. et al. (2014) 'Levels And Sources Of Volatile Organic Compounds In Homes Of Children With Asthma', Indoor Air, 24(4), pp. 403-415.

Clough, S. R. (2014) 'Xylene', Encyclopedia of Toxicology: Third Edition, 4(0), pp. 989-992.

Egeghy, P. P., Tornero-Velez, R. and Rappaport, S. M. (2000) 'Environmental And Biological Monitoring Of Benzene During Self-Service Automobile Refueling', Environmental Health Perspectives, 108(12), pp. 1195-1202.

EPA (2002) Toxicological Review of Benzene (Noncancer Effects), U.S. Environmental Protection Agency. Washington, DC.

Erini Meilina Bestari, Sudarmaji, L. S. (2019) 'Sumber Benzena, Karakteristik Dan Kadar Hemoglobin Mekanik Bengkel, Motor AHASS Kota Kediri', Jurnal Kesehatan Lingkungan, 11(4), pp. 293-299.

Fahmi, A. N. (2017) Analisis Hubungan Pajanan Senyawa Benzena dan Toluena Terhadap Profil Darah Pekerja Di Sentra Industri. Undergraduate Thesis. Surabaya: Faculty of Public Health, Universitas Airlangga.

Faisal, H. D. and Susanto, A. D. (2019) 'Peran Masker/Respirator Dalam Pencegahan Dampak Kesehatan Paru Akibat Polusi Udara', Jurnal Respirasi, 3(1), pp. 18-25.

Febriantika, D., Sulistyani, S. and Budiyono, B. (2017) 'Analisis Risisko Kesehatan Pajanan Benzena Di Industri Percetakan X Kota Semarang', Jurnal Kesehatan Masyarakat Universitas Diponegoro, 5(1), pp. 430-437.

Frizka, M. and Martiana, T. (2017) 'Hubungan Antara Karakteristik Individu Unit Kerja Dan Faktor Ergonomi Dengan Keluhan Kesehatan Di Industri Kecil Sepatu Kota Mojokerto', The Indonesian Journal of Occupational Safety and Health, 6(3), pp. 37-47.

Irmasari, F. (2018) 'Kadar Toluen di Udara Lingkungan Kerja Berkorelasi Terhadap Kadar Asam Hipurat Urine Pada Pekerja Percetakan Di Rungkut Surabaya', Jurnal Kesehatan Lingkungan, 10(3), pp. 328-335.

Jayanth, S. H. et al. (2017) 'Glue Sniffing', The Medico-legal journal, 85(1), pp. 38-42.

Kandyala, R., Raghavendra, S. P. and Rajasekharan, S. (2010) 'Xylene: An Overview Of Its Health Hazards And Preventive Measures', Journal of Oral and Maxillofacial Pathology, 14(1), pp. $1-5$. 
Kasemy, Z. A. et al. (2019) 'Environmental And Health Effects Of Benzene Exposure Among Egyptian Taxi Drivers', Journal of Environmental and Public Health, 2019(7), pp. 1-6.

Keer, S. et al. (2017) 'Neuropsychological Performance In Solvent-Exposed Vehicle Collision Repair Workers In New Zealand', PLoS ONE, 12(12), pp. 1-16.

Khan, A. A., Sultan, R. and Rahman, S. U. (2013) 'Biochemical And Hematological Analysis After Exposure To Hazardous Materials During Shoe Making', Journal of Biology and Life Science, 4(2), pp. 116-138.

Kumar, S. and Subhashini (2015) 'Health Hazards of Organic Solvents', Research and Reviews: Journal of Chemistry, 4(2), pp. 90-95.

Laelasari, E., Kristanti, D. and Rahmat, B. (2018) 'Penggunaan Lem Sepatu Dan Gangguan Kesehatan Pekerja Industri Sepatu Di Ciomas, Bogor', Jurnal Ekologi Kesehatan, 17(2), pp. 85-95.

Marganda, S., Ashar, T. and Nurmaini, N. (2018) 'The Effect of Toluene Exposure on Central Nervous Disorder among Printing Workers', Indonesian Journal of Medicine, 3(3), pp. 125-133.

Nikmah, W., Darundiati, Y. and Budiyono, B. (2016) 'Hubungan Antara Paparan Benzena Dengan Profil Darah Pada Pekerja Di Industri Percetakan X Kota Semarang', Jurnal Kesehatan Masyarakat Universitas Diponegoro, 4(5), pp. 213-219.

Pratamasari, F., Setyopranoto, I. and Soebijanto, S. (2016) 'Pajanan Toluen Udara dan Kejadian Neuropati Saraf Tepi di Percetakan Offset', Berita Kedokteran Masyarakat, 32(10), pp. 359-366.

Rauf, S. et al. (2015) 'Occupational Contact Dermatitis Among Workers Of Small Shoe Making Factories', Pakistan Journal of Medical and Health Sciences, 9(3), pp. 911-912.

Resdwivani, D. M. (2018) 'Kadar Benzene Di Udara, Kadar Asam Trans,Trans- Muconic Dalam Urine Dan Gangguan Kesehatan Pekerja SPBU X Di Jakarta Selatan', Jurnal Kesehatan Lingkungan, 10(2), pp. 159-164.

Saadatuddaroini, S. and Keman, S. (2019) 'Korelasi Masa Kerja, Jam Kerja Terhadap Kadar t,tMuconic Acid Urin Pekerja Terpapar Benzena di Pertambangan Minyak Tradisional Bojonegoro', The Indonesian Journal of Occupational Safety and Health, 8(1), pp. 115-123.
Setiowati, D. (2018) 'Kadar Fenol Urine Tinggi dan Keluhan Kesehatan Pada Pekerja Terpajan Benzena di Industri Kecil Sandal Wedoro Sidoarjo', Jurnal Kesehatan Lingkungan, 10(4), pp. $402-408$.

Singh, A.K., Neetu, T and Jain, C. L. (2012) 'Monitoring, Assessment And Status Of Benzene, Toluene And Xylene Pollution In The Urban Atmosphere Of Delhi, India', Research Journal of Chemical Sciences, 2(4), pp. 2231-606.

Siregar, A. F., Ashar, T. and Nurmaini (2019) 'Paparan Benzena Di Udara Ambien Dan Kadar TransTrans Muconic Acid Urin Pada Pekerja Industri Percetakan Di Kota Medan', Berita Kedokteran Masyarakat, 35(3), pp. 107-112.

Syafar, M. and Wahid, A. (2015) 'Analysis Of Benzene Concentration Effects At Workplace To The Phenol Concentration In Urine Of Painting Workshop Labors In Makassar, Indonesia', International Journal of Science: Basic and Applied Research, 21(2), pp. 439-445.

Thetkathuek, A. et al. (2015) 'Neuropsychological Symptoms Among Workers Exposed To Toluene And Xylene In Two Paint Manufacturing Factories In Eastern Thailand', Advances in Preventive Medicine, 2015(August), pp. 1-10.

Vermeulen, R. et al. (2004) 'Detailed Exposure Assessment For A Molecular Epidemiology Study Of Benzene In Two Shoe Factories In China', Annals of Occupational Hygiene, 48(2), pp. 105-116.

Wispriyono, B. and Handoyo, E. (2016) 'Risiko Kesehatan Pajanan Benzena, Toluena Dan Xylena Petugas Pintu Tol', Jurnal Kesehatan Masyarakat, 11(2), pp. 96-102.

Wulandari, P. et al. (2018) 'Urinary S-Phenylmercapturic Acid (S-PMA) Level As Biomarkers Of Exposure To Benzene In Informal Shoes Industrial Workers, Cibaduyut Bandung', KnE Life Sciences, 4(1), pp. 84-92.

Yunita, I. (2016) Hubungan Praktik Kerja, Pajanan Benzena Dan Kebiasaan Merokok Dengan Konsentrasi Benzena Dalam Urin, Jurnal Kesehatan Masyarakat. Undergraduate Thesis. Semarang: Faculty of Public Health, Universitas Muhammadiyah Semarang. 